Terakreditasi

Ditjen Penguatan Riset dan Pengembangan, Kemenristekdikti

Keputusan No: 21/E/KPT/2018, Tanggal 9 Juli 2018
Januari 2020, 7(1):8-14

DOI: http://dx.doi.org/10.33772/jitro.v7i1.8590

http://ojs.uho.ac.id/index.php/peternakan-tropis

\title{
Performa Ayam Sentul yang Diberi Ransum Mengandung Indigofera zollingeriana
}

\author{
Asep Suherman $^{1 *}$, Yudhi Mahmud ${ }^{1}$, Wiwik Ambasari ${ }^{1}$, Iman Hernaman ${ }^{2}$, \\ Hani Yuhani ${ }^{3}$, Rukmantoro Salim ${ }^{3}$ \\ 1) Fakultas Pertanian Universitas Wiralodra \\ Jalan Ir. H. Juanda KM.03 Singaraja, Indramayu Jawa Barat, Indonesia 45213 \\ ${ }^{2)}$ Fakultas Peternakan Universitas Padjadjaran \\ J1. Raya Bandung-Sumedang Km. 21 Jatinangor Sumedang 45363 \\ ${ }^{3)}$ Badan Penelitian dan Pengembangan Daerah Provinsi Jawa Barat \\ J1. Kawaluyaan Indah Raya No. 6, Buah Batu Kota Bandung 40286 \\ Email korespondensi: rizqi_ovie_suherman@yahoo.co.id
}

(Diterima: 01-09-2019; disetujui 10-12-2019)

\begin{abstract}
ABSTRAK
Penelitian ini bertujuan untuk memanfaatkan Indigofera zollingeriana dalam ransum terhadap kinerja ayam sentul. Seratus empat puluh empat ekor ayam Sentul dialokasikan ke dalam 6 perlakuan dan 4 ulangan. Unggas tersebut dipelihara dari mulai day old chick (DOC) sampai umur 3 minggu dengan diberi ransum BR $501 \mathrm{CP}$, selanjutnya selama 7 minggu diberi ransum perlakuan. Ransum perlakuan tersebut adalah 1) R1 = ransum komersial, 2) R2 = ransum yang biasa digunakan peternak, 3) R3 = ransum mengandung Indigofera zollingeriana 20\% tanpa jagung, 4) R4 = ransum mengandung Indigofera zollingeriana 10\%, 5) R5 = ransum mengandung Indigofera zollingeriana 15\%, 6) R6 = ransum mengandung Indigofera zollingeriana $20 \%$ dan mengandung jagung. Penelitian menggunakan rancangan acak lengkap dan data yang terkumpul dianalisis dengan uji Duncan. Hasil menunjukkan bahwa konsumsi dan konversi ransum tidak menunjukan perbedaan yang nyata, tapi pertambahan bobot badan tertinggi $(\mathrm{P}<0,05)$ dicapai pada $\mathrm{R} 1$ dengan bobot badan akhir sebesar 833,25 g pada umur 10 minggu. Ransum R4 yang mengandung Indigofera zollingeriana $10 \%$ menghasilkan pertambahan bobot badan yang sama dengan R1 dengan bobot akhir penelitian sebesar $722 \mathrm{~g}$. Kesimpulan Indigofera zollingeriana sebanyak 10\% dapat diberikan dalam ransum ayam sentul.
\end{abstract}

Kata kunci: ayam sentul, performa, Indigofera zollingeriana

\section{ABSTRACT}

This study was aimed to utilize Indigofera zollingeriana in diets on the performance of sentul chicken. One hundred and fourty four sentul chickens were allocated into 6 treatments and 4 repetitions. This poultry was kept from DOC until the age of 3 weeks with BR $501 \mathrm{CP}$ diets, next for 7 weeks fed treatment diets. The treatment diet was 1) R1 = commercial diet, 2) R2 = diet commonly used by breeder, 3) R3 = diet containing Indigofera zollingeriana $20 \%$ without maize, 4) R4 = diet containing Indigofera zollingeriana 10\%, 5) R5 = diet containing Indigofera zollingeriana 15\%,6) R6 = diet containing Indigofera zollingeriana $20 \%$ and containing maize. The study used a complete randomized design and the collected data were analyzed by Duncan test. The results showed that the consumption and conversion of diets did not show any significant difference, but the highest body weight gain $(\mathrm{P}<0.05)$ was achieved in $\mathrm{R} 1$ with final bodyweight of $833.25 \mathrm{~g}$ at 10 weeks. The R4 diet containing 10\% Indigofera zollingeriana resulted in the same weight gain as R1 with the final weights of $722 \mathrm{~g}$. Conclusion Indigofera zollingeriana as much as $10 \%$ can be given in sentul chicken diets.

Keywords: performance, Indigofera zollingeriana, sentul chicken 


\section{PENDAHULUAN}

Kontribusi ayam lokal terhadap produksi daging unggas cukup tinggi (Ditjen PKH, 2018). Besarnya permintaan akan produk ayam Lokal ternyata belum mampu dipenuhi oleh peternak terutama bila permintaan dalam jumlah besar dan kontinu. Ayam sentul merupakan ayam lokal yang berasal dari wilayah Kabupaten Ciamis (Nataamijaya et al., 1995). Namun perkembangannya sudah menyebar terutama di Wilayah Jawa Barat. Ayam sentul mempunyai pertumbuhan yang relatif cepat (Kurnia, 2011). Unggas ini bila dipelihara intensip akan mencapai bobot badan sebesar 1,60-2,20 kg, sedangkan dipelihara dengan cara dilepas, bobot badan hanya 1,10-1,60 kg (Nataamijaya \& Diwyanto, 1994; Nataamijaya, 1996, 2000; Nataamijaya et al., 2003).

Peningkatan kinerja ayam sentul dapat dilakukan melalui perbaikan kuantitas dan kualitas pakan yang diberikan. Penyusunan ransum unggas tidak terlepas dari penggunaan tepung ikan sebagai bahan pakan sumber protein. Namun demikian penggunaannya sering dibatasi karena harganya lebih mahal. Disisi lain ketersediaan jagung kuning untuk bahan baku pakan unggas sebagai sumber energi utama di beberapa tempat sulit untuk didapat, sehingga perlu dibuat formulasi ransum tanpa jagung untuk mengantisipasi kelangkaan jagung kuning.

Indigofera zollingeriana adalah sejenis legum yang memiliki kandungan protein tinggi, diduga dapat menggantikan sebagian tepung ikan. Menurut Sirait et al. (2009), Indigofera zollingeriana dapat berproduksi secara optimum pada umur delapan bulan dengan rata-rata produksi biomasa segar per pohon sekitar 2,595 kg/panen, rasio produksi daun per pohon $967,75 \mathrm{~g} /$ panen $(37,29 \%)$ dan produksi batang per pohon 1627,25 g/panen $(63,57 \%)$ dengan total produksi segar sekitar 52 ton/ha/tahun. Menurut Akbarillah et al. (2002) bahwa tepung daun Indigofera $s p$. mengandung protein kasar (PK) sebesar 27,9\%, serat kasar (SK) sebesar 15,25\%, Ca 0,22\%, P $0,18 \%$. Disamping itu pula mengandung xanthophyll dan karotenoid seperti yang terdapat pada jagung kuning yang memberikan warna kuning pada kuning telur (egg yolk). Oleh karena itu, penggunaan Indigofera zollingeriana dapat memberikan alternatif sumber xanthophyll dan karatenoid dalam ransum yang tidak menggunakan jagung kuning. Senyawa tersebut juga memberikan warna bagi daging ayam. Warna kuning pada yolk telur dan daging lebih disukai (Resnawati, 2005) dibandingkan dengan daging warna pucat. Penelitian ini bertujuan untuk melihat kinerja ayam sentul yang diberi ransum mengandung Indigofera zollingeriana.

\section{MATERI DAN METODE}

Penelitian dilaksanakan di peternakan ayam kampung milik Gabungan Kelompok Tani Ganda Sari yang berlokasi di Kecamatan Sliyeg, Kabupaten Indramayu. Sejumlah 144 ekor ayam sentul jantan dan betina dipelihara dari mulai DOC dengan diberi ransum komersial BR 501 CP selama 3 minggu pertama. Setelah itu dialokasikan secara acak ke dalam 6 macam ransum perlakuan yang terbagi ke dalam 4 ulangan dan dipelihara selama 7 minggu. Setiap kandang terdiri atas 6 ekor ayam Sentul yang di dalamnya terwakili ayam jantan dan betina. Ayam sentul tersebut dipelihara dalam kandang panggung yang terbuat dari bilah bambu. Kandang tersebut dilengkapi dengan tempat pakan dan minum. Ransum dan air minum diberikan secara ad libitum dan pemberiannya dilakukan 2 kali sehari, yaitu pada pagi hari jam 07.00-08.00 dan sore hari pukul 16.00-17.00.

Ransum perlakuan disusun sendiri yang terdiri atas jagung, dedak menir, bungkil kedele, minyak kelapa, tepung ikan dan tepung Indigofera zollingeriana, kecuali ransum kontrol 1 (R1) merupakan ransum komersial dan R2 merupakan ransum kontrol 2 (R2) yaitu ransum yang disusun dan biasa diberikan oleh peternak. Sementara itu, R3, R4, R5, dan R6 adalah ransum yang mengandung Indigofera zollingeriana yang diposisikan tidak tersedia tepung jagung, yaitu ransum R3 dan R5. Adapun ransum perlakuan tersebut disajikan pada Tabel 1.

Peubah yang diukur adalah konsumsi ransum, pertambahan bobot badan (PBB), konversi ransum/feed convertion ratio (FCR) (Gustira, 2015). Data yang terkumpul dilakukan analisis Duncan (Steel \& Torie, 1996). 
Tabel 1. Susunan bahan pakan dan kandungan zat makanan ransum percobaan

\begin{tabular}{|c|c|c|c|c|c|c|}
\hline Bahan Pakan & R1 & $\mathrm{R} 2$ & R3 & $\mathrm{R} 4$ & R5 & R6 \\
\hline & \multicolumn{6}{|c|}{$\%$ dalam pakan } \\
\hline Jagung & \multirow{5}{*}{$\begin{array}{c}\text { Pakan } \\
\text { Komersial }\end{array}$} & 0,00 & 0,00 & 30,00 & 0,00 & 20,00 \\
\hline Dedak & & 72,00 & 62,00 & 50,00 & 54,00 & 55,00 \\
\hline Menir & & 13,00 & 13,00 & 0,00 & 26,00 & 0,00 \\
\hline Tepung Ikan & & 15,00 & 5,00 & 10,00 & 5,00 & 5,00 \\
\hline $\begin{array}{l}\text { Tepung Indigofera } \\
\text { zollingeriana }\end{array}$ & & 0,00 & 20,00 & 10,00 & 15,00 & 20,00 \\
\hline Total & & 100,00 & 100,00 & 100,00 & 100,00 & 100,00 \\
\hline Kandungan Zat Makanan*) & \multicolumn{6}{|c|}{$\%$ bahan kering } \\
\hline $\mathrm{Abu}$ & 11,81 & 10,85 & 9,37 & 9,08 & 6,12 & 5,07 \\
\hline Protein Kasar & 21,43 & 20,46 & 19,03 & 21,42 & 21,53 & 21,71 \\
\hline Serat Kasar & 7,17 & 4,86 & 5,36 & 7,93 & 8,65 & 8,87 \\
\hline Lemak Kasar & 6,43 & 7,35 & 7,29 & 6,13 & 5,95 & 5,43 \\
\hline BETN & 53,16 & 56,48 & 58,95 & 55,44 & 57,75 & 58,92 \\
\hline Energi Metabolis**) & & & & & & \\
\hline $\mathrm{Kkal} / \mathrm{kg}$ & 2571,25 & 2604,4 & 2625,65 & 2545,75 & 2529,6 & 2540,65 \\
\hline
\end{tabular}

Keterangan : ${ }^{*}$ Hasil analisis laboratorium

**) Perhitungan berdasarkan 70-90 \% GE (Schaible, 1979)

\section{HASIL DAN PEMBAHASAN}

\section{Konsumsi Harian}

Pakan yang dikonsumsi oleh ternak unggas sangat menentukan pertambahan bobot badan sehingga berpengaruh terhadap efisiensi suatu usaha peternakan. Syarat pakan yang dikonsumsi harus berkualitas baik yaitu mengandung zat makanan yang sesuai dengan kebutuhan ternak unggas (Uzer et al., 2013). Hasil pengamatan selama penelitian menunjukan bahwa konsumsi harian tidak berbeda nyata (Tabel 2). Konsumsi tertinggi diperoleh pada perlakuan R1 dan terendah perlakuan R2, masing-masing 57,17 g dan 54,60 g.

Hasil ini disebabkan kandungan energi dalam ransum relatif sama dengan kisaran 2529,6$2625,65 \mathrm{kkal} / \mathrm{kg}$, Kebutuhan energi ini relatif sama dengan yang direkomendasi oleh Iskandar et al. (1998) bahwa kebutuhan energi metabolis ayam kampung petelur umur 0-12 minggu dengan energi metabolis $2600 \mathrm{kkal} / \mathrm{kg}$.

Kandungan energi dalam pakan akan berpengaruh terhadap kapadatan energi pakan dan secara proporsial mempengaruhi konsumsi pakan harian (Zuprizal, 1993). Tingkat energi dalam ransum menentukan banyaknya pakan yang dikonsumsi (Wahju, 1985). Unggas akan berhenti makan jika kebutuhan energinya terpenuhi. Faktor lain yang mempengaruhi konsumsi ransum menurut Widodo (2009) adalah temperatur lingkungan, kesehatan ayam, perkandangan, wadah pakan, kandungan zat makanan dalam pakan dan stress yang terjadi pada ternak unggas. Konsumsi pakan juga dipengaruhi dari besarnya (size) ternak
(Wahju, 1985). Namun faktor ini sudah dibatasi dengan memberikan kondisi yang sama pada semua perlakuan. Kehadiran Indigofera zollingeriana tidak berpengaruh terhadap konsumsi ransum.

\section{Pertambahan Bobot Badan}

Perkembangan bobot badan ayam sentul antara umur 4-10 minggu disajikan pada Gambar 1. Pada gambar tersebut terlihat bahwa terjadi peningkatan bobot badan seiring dengan pertambahan umur ayam tersebut, meskipun pertambahan tersebut mengalami perlambatan pada minggu ke-9. Setelah itu terjadi peningkatan secara cepat. Bobot akhir berkisar antara 722,00-833,25g, dengan bobot akhir tertinggi dicapai pada perlakuan R1, yaitu ransum komersial, sedangkan bobot akhir terendah diperoleh pada ransum R2, ransum yang tidak mengandung Indigofera zollingeriana.

Bobot akhir pada umur 10 minggu masih di bawah bobot akhir dari ayam silangan sentul $\mathrm{x}$ kampung dan pelung $\mathrm{x}$ sentul, masing-masing sebesar 1,123 dan $923 \mathrm{~g}$. Jika dibandingkan dengan hasil penelitian Meyliyana et al. (2013) yang dilakukan pada kelompok Ciung Wanara di Ciamis menunjukkan bobot akhir ayam sentul pada umur 8 minggu sebesar 616,71, maka hasil penelitian ini juga masih di bawah rata-rata. Hal ini diduga karena adanya perbedaan lingkungan dan sumber bibit yang diperoleh yang digunakan dalam penelitian ini. Kurnia (2011) menyatakan bahwa faktor genetik dan lingkungan mempengaruhi laju pertumbuhan bobot badan ayam sentul. 


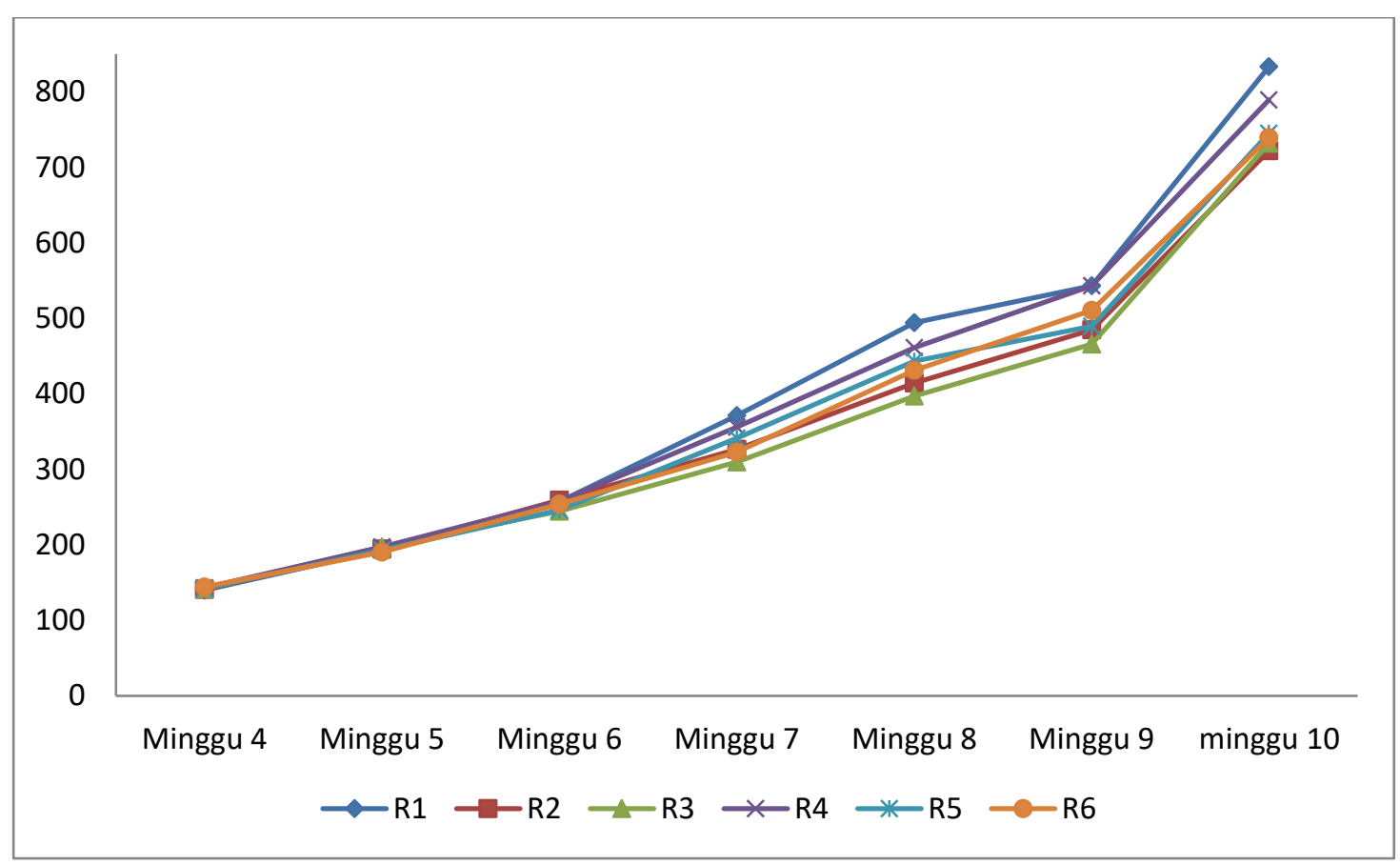

Gambar 1. Perkembangan bobot badan (g) ayam sentul periode umur 4-10 minggu

Pertambahan bobot badan selama 7 minggu percobaan menunjukan adanya perbedaan yang nyata $(\mathrm{P}<0,05)$. Nilai $\mathrm{PBB}$ tertinggi diperoleh pada perlakuan R1, yaitu perlakuan menggunakan ransum komersial, namun hasilnya relatif sama dengan perlakuan $\mathrm{R} 4$ yang merupakan ransum mengandung Indigofera zollingeriana $10 \%$, dimana PBB untuk masing masing perlakuan tersebut sebesar 14,44 dan 13,46 g/hari. Hasil ini lebih tinggi dibandingkan dengan penelitian yang dilakukan oleh Nurhayati (2001) yaitu sebesar 10,04 g/hari.

Penggunaan ransum komersial yang lebih tinggi terhadap PBB karena ransum ini disusun untuk memberikan kebutuhan yang cukup bagi ayam serta memiliki komposisi nutrien yang seimbang, disamping itu juga biasanya mengandung zat perangsang tumbuh, seperti antibiotik. Perlakuan R4, yang mengandung Indigofera zollingeriana $10 \%$ memiliki PBB lebih tinggi dibandingkan dengan perlakuan lainnya terutama dengan perlakuan R2 tanpa Indigofera zollingeriana dan menggunakan $100 \%$ sumber protein yang berasal dari tepung ikan. Menurut Palupi et al. (2014) bahwa tepung pucuk Indigofera $s p$. memiliki kandungan asam amino yang lengkap. Lebih lanjut dinyatakan bahwa skor asam amino tepung pucuk Indigofera $s p$. mendekati skor asam amino yang dimiliki bungkil kedelai. Oleh karena itu, dapat dikatakan bahwa kualitas protein dari tepung pucuk Indigofera $s p$. mempunyai kualitas yang baik dan dapat digunakan sebagai salah satu bahan pakan sumber protein. Untuk itu penggunaan Indigofera zollingeriana dapat menggantikan sebagian dari tepung ikan sebagai sumber protein dalam ransum unggas.

Jika dilihat dari komposisi zat makanan, tampak bahwa nilai protein tidak terlalu berbeda jauh, begitupula dengan nutrien lainnya, namun jika dilihat dari kandungan serat kasarnya tampak ransum R4 lebih rendah dibandingkan dengan perlakuan R5 dan R6, dimana ransum tersebut mengandung Indigofera zollingeriana lebih tinggi (Tabel 1). Indigofera zollingeriana sebagai tanaman legum mengandung serat kasar yang cukup tinggi, sehingga peggunaannya yang lebih besar dalam ransum akan meningkatkan kandungan serat kasar yang tinggi. Serat kasar dalam ransum unggas tidak dapat dicerna dan mengganggu kecernaan nutrien lainnya, akibatnya pengggunaan yang tinggi dalam ransum akan mengganggu pertumbuhan. Unggas memiliki keterbatasan dalam mencerna serat kasar karena tidak dapat memproduksi enzim selulase, sehingga serat kasar yang tinggi secara keseluruhan dapat membawa zat-zat makanan yang dapat dicerna keluar bersama feses (Wahyu, 1997). 
Tabel 2. Performa ayam sentul yang diberi ransum perlakuan

\begin{tabular}{lcccccc}
\hline \multicolumn{1}{c}{ Perlakuan } & R1 & R2 & R3 & R4 & R5 & R6 \\
\hline Konsumsi BK harian & $57,17 \pm 0,43$ & $54,60 \pm 1,28$ & $54,74 \pm 0,50$ & $56,00 \pm 0,46$ & $55,41 \pm 0,48$ & $57,09 \pm 6,63$ \\
(g/hari) & & & & & & \\
PBB (g/hari) & $14,44 \pm 0,88^{\mathrm{b}}$ & $12,11 \pm 0,80^{\mathrm{a}}$ & $12,29 \pm 0,83^{\mathrm{a}}$ & $13,46 \pm 0,43^{\mathrm{ab}}$ & $12,57 \pm 1,76^{\mathrm{a}}$ & $12,40 \pm 0,421^{\mathrm{a}}$ \\
Konversi ransum & $3,97 \pm 0,25$ & $4,53 \pm 0,34$ & $4,47 \pm 0,30$ & $4,16 \pm 0,11$ & $4,48 \pm 0,64$ & $4,62 \pm 0,71$ \\
\hline
\end{tabular}

Keternang: $\mathrm{BK}=$ bahan kering, $\mathrm{PBB}=$ pertambahan bobot badan, superskrip yang berbeda pada baris yang sama menunjukkan perbedaan yang nyata $(\mathrm{P}<0,05)$

Bila dibandingkan dengan $\mathrm{R} 2$ dan $\mathrm{R} 3$, perlakuan R4 juga masih lebih tinggi PBB-nya, meskipun pada ransum R2 tidak mengandung Indigofera zollingeriana. Susunan bahan pakan pada ransum R2 dan R3 mengandung dedak padi yang tinggi sebesar $72 \%$ dan $62 \%$. Dedak padi banyak mengandung asam fitat. Halloran (1980) melaporkan bahwa dedak padi mengandung $1,44 \%$ fosfor dan $80 \%$ di antaranya dalam bentuk fitat. Bagi ternak monogastrik fitat juga merupakan antinutrien karena mempunyai sifat sebagai chelating agent terutama terhadap ion-ion bervalensi dua seperti Ca, Fe, dan Zn (Graf, 1983) sehingga mengakibatkan ketersediaan biologik mineral-mineral tersebut rendah. Hal ini menyebabkan asupan mineral bagi pertumbuhan menjadi berkurang. Seperti diketahui bahwa ransum R4 merupakan ransum yang biasa digunakan oleh kelompok peternak di tempat penelitian dan sebagai ransum kontrol.

Jagung dalam ransum R4 juga membantu sebagai sumber antioksidan yang melindungi sel tubuh dari radikal bebas, selain sebagai sumber energi potensial bagi hewan ruminansia (Kumar \& Jhariya, 2013). Dengan demikian kehadiran jagung dalam ransum akan membantu mempercepat pertumbuhan.

\section{Konversi Ransum}

Konversi ransum didefinisikan sebagai
jumlah pakan yang dibutuhkan untuk menghasilkan satu kilogram bobot hidup, dengan cara menghitung rasio antara konsumsi pakan dengan pertambahan bobot badan ayam Nilai konversi ransum yang semakin kecil berarti efisiensi pakan semakin baik. Dengan memperbaiki nilai konversi ransum akan berefek terhadap emisi lingkungan dan dapat menurunkan dampak buruk dari hewan produksi terhadap lingkungan (Adrianto et al., 2015).

Konversi ransum ayam sentul hasil penelitian menunjukan rata-rata mencapai 3,974,62. Hasil ini berada pada kisaran hasil penelitian Sopian et al. (2015), dimana pada umur 10 minggu konversi ransum mencapai 4,11 untuk ayam silangan pelung dan sentul. Perbedaan ini diduga dipengaruhi oleh beberapa faktor diantaranya kualitas bibit DOC, kualitas nutrisi (air, pakan), kualitas manajemen pemeliharaan, dan kualitas kandang (Adrianto et al., 2015).

Hasil analisis dengan mengunakan uji Duncan menunjukan bahwa tidak ada perbedaan yang nyata diantara perlakuan. Artinya semua perlakuan menghasilkan tingkat efisiensi yang sama. Pada hakekatnya konversi ransum merupakan hasil dari jumlah ransum yang dikonsumsi dengan pertambahan bobot badan yang dihasilkan. Melihat bahwa jumlah konsumsi yang relatif sama (Tabel 2) dengan pertambahan bobot badan yang tidak terlalu jauh selisihnya, meskipun terdapat perbedaan nyata antara ransum R1 dan R4 dengan ransum perlakuan lainnya, tampaknya akan menghasilkan konversi ransum yang sama. Dengan kata lain penggunaan Indigofera zollingeriana memberikan tingkat efisiensi yang sama sampai $20 \%$ dalam ransum sampai umur 10 minggu. Namun demikian hal ini perlu kajian lebih lanjut, karena semakin lama dipelihara kemungkinan pertambahan bobot badan akhir akan memberikan perbedaan yang cukup lebar, yang menyebabkan waktu panen akan berbeda.

\section{KESIMPULAN}

Penggunaan Indigofera zollingeriana dalam ransum ayam sentul sebanyak $20 \%$ tidak memberikan dampak terhadap konversi ransum, namun berdampak pada penurunan pertambahan bobot badan. Penggunaan sebanyak 10\% Indigofera zollingeriana lebih dianjurkan dalam ransum ayam sentul.

\section{UCAPAN TERIMA KASIH}

Terimakasih disampaikan kepada Badan Penelitian dan Pengembangan Daerah Provinsi Jawa Barat yang telah mendukung penelitian ini melalui dana hibah untuk tahun anggaran 2017. 


\section{PUSTAKA}

Andriyanto, A.S. Satyaningtijas, R. Yufiandri, R. Wulandari, V. M. Darwin, \& S.N.A. Siburian. 2015. Performa dan kecernaan pakan ayam broiler yang diberi hormon testosteron dengan dosis bertingkat. Acta Veterinaria Indonesiana 3(1):29-37.

Akbarillah T.D., Kaharuddin, \& Kususiyah. 2002. Kajian daun tepung Indigofera sebagai suplemen pakan produksi dan kualitas telur. Dalam: Laporan penelitian. Lembaga Penelitian Universitas Bengkulu. Bengkulu.

Ditjen PKH. 2018. Statistik Peternakan dan Kesehatan Hewan. Penerbit Kementerian Pertanian, Direktorat Peternakan dan Kesehatan Hewan. Jakarta.

Gustira, D.E., Riyanti, \& T. Kurtini. 2015. Pengaruh kepadatan kandang terhadap performa produksi ayam petelur fase awal grower. Jurnal Ilmiah Peternakan Terpadu 3(1):87-92.

Graf, E. 1983. Calcium binding to phytic acid. J Agric and Food Chem. 31:851-855.

Halloran, H.R. 1980. Phytate phosphorus in feed formulation. Feedstuffs.

Kumar, D., \& A.N. Jhariya. 2013. Nutritional, medicinal and economical importance of corn: A mini review. Res. J Pharm Sci. 2:78.

Kurnia, Y. 2011. Morfometrik Ayam Sentul, Kampung dan Kedu pada Fase Pertumbuhan dari Umur 1-12 Minggu. Karya Ilmiah. Program Alih Jenis. Departemen Produksi dan Teknologi Peternakan, Fakultas Peternakan, Institut Pertanian Bogor. Bogor.

Meyliyana, S.Mugiyono, \& Roesdiyanto. 2013. Bobot badan berbagai jenis ayam sentul di gabungan kelompok tani ternak ciung wanara kecamatan ciamis kabupaten ciamis. Jurnal Ilmiah Peternakan 1(3):985-992.

Nataamijaya, A.G. 2000. The native of chiken of Indonesia. Bull Plasma Nutfah 6 (1):1-6.

Nataamijaya, A.G. 2005. Karakteristik penampilan pola warna bulu, kulit, sisik, dan paruh ayam pelung di Garut dan ayam sentul di Ciamis. Bull Plasma Nutfah 10(1):1-10.

Nataamijaya, A.G., K. Diwyanto, Haryono, E. Sumantri, \& M. Kusni. 1994. Karakteristik morfologis delapan varietas ayam bukan ras (Buras) langka. Pros. Seminar Nasional Sains dan Teknologi Peternakan. Ciawi Bogor, 25-26 Januari 1994. Balai Penelitian Ternak, Puslitbang Peternakan, Bogor. hlm. 605-614.

Nataamijaya, A.G., K. Diwyanto, S.N. Jarmani, \& Haryono, 1995. Konservasi Ayam Buras Langka (Pelung, Nunukan, Gaok, Kedu Putih dan Jenis Ayam Buras Lainnya). Laporan Kemajuan Penelitian Balai Penelitian Ternak, Ciawi, Bogor bekerjasama dengan Proyek Pemanfaatan dan Pelestarian Plasma Nutfah Pertanian, Bogor. hlm. 1-20.

Nataamijaya, A.G., S.N. Jarmani, \& T. Sartika. 1996. Konsep Strategi Penanganan Pelestarian Plasma Nutfah Pertanian Secara Ex-situ Ternak Ayam Buras. Proyek Pemanfaatan dan Pelestarian Plasma Nutfah Pertanian. Bogor.

Nataamijaya, A.G., A.R. Setioko, B. Brahmantyo, \& K. Diwyanto. 2003. Performans dan karakteristik tiga galur ayam lokal (pelung, arab, sentul). Pros. Seminar Nasional Teknologi Peternakan dan Veteriner. Bogor, 29-30 September 2003. Puslitbang Peternakan, Bogor. hlm. 353-359.

Nurhayati, A. 2001. Studi fenotif ayam sentul di Kecamatan Cipaku Kabupaten Ciamis Jawa Barat. Fakultas Peternakan Institut Pertanian Bogor. Bogor.

Palupi, R., L. Abdullah, Astuti, \& D.A., Sumiati. 2014. Potensi dan pemanfaatan tepung pucuk Indigofera $s p$. sebagai bahan pakan substitusi bungkil kedelai dalam ransum ayam petelur. JITV 19 (3):210-219.

Resnawati, H. 2005. Preferensi konsumen terhadap daging dada ayam pedaging yang diberi ransum menggunakan tepung cacing tanah (Lumbricus rubellus). Seminar Nasional Teknologi Peternakan dan Veteriner. Bogor, 12-13 September 2005. Puslitbang Peternakan, Bogor. hlm. 744-748.

Schaible, P.J. 1979. Poultry Feed and Nutrition. The Avi Publishing Inc. New York.

Sirait, J., K. Simanihuruk, \& R. Hutasoit. 2009. The potency of Indigofera sp. as goat feed: production, nutritive value and palatability. In: Proceeding of International Seminar on Forage Based Feed Resources. Bandung, 3- 
7 Agustus 2009. Food and Fertilizer Technology Centre (FFTC) ASPAC, Livestock Research Centre-COA, ROC and IRIAP. Taipe. p. 4-7.

Sopian, Y., S. Darwati, \& C. Sumantri. 2015. Performa F1 antara ayam aentul x kampung dan ayam pelung $\mathrm{x}$ sentul pada umur $0-12$ minggu. Jurnal Ilmu Produksi dan Teknologi Hasil Peternakan 3(3):131-137.

Steel, R.G.D. \& J.H. Torrie. 1996. Prinsip dan Prosedur Statistika. Diterjemahkan oleh Bambang Sumantri. Gramedia Pustaka Utama. Jakarta.

Uzer, F., N. Iriyanti, \& Roesdiyanto. 2013. Penggunaan pakan fungsional dalam ransum terhadap konsumsi pakan dan pertambahan bobot badan ayam broiler. Jurnal Ilmiah Peternakan 1(1):282-288.

Wahju, J. 1997. Ilmu Nutrisi Unggas. Cerakan keempat. Gajah Mada University Press. Yogyakarta.

Widodo, I. 2009. Pengaruh penambahan mineral supplement "biolife" dalam pakan terhadap penampilan produksi ayam pedaging. Karya Ilmiah. Universitas Brawijaya. Malang.

Zuprizal, M. Larbier, A.M. Chagneau, \& P.A. Geraert. 1993. Influence of ambient temperature on true digestibility of protein and amino acids of rapeseed and soybean meals in broilers. Poultry Sci. 72:289-295. 